\title{
Understanding Women-Nature Dynamics: Eco-consciousness as a Quest for Identity in Selected Texts from Assam
}

\author{
Paloma Chaterji \\ Research Coordinator in Organic Studies at M.G.gramudyog. \\ E-mail: chaterjipaloma@yahoo.in, ORCID:345382637
}

\begin{abstract}
My paper will explore the constantly changing dynamics of women-nature relationship through social and cultural history of Assam. I will gradually explore the eco-consciousness and the changing principles of my subjects as I shift my focus from the Shakti cult, to the Vaishnavite, to the modern urbanised subjects of the texts. The women characters in these texts will be the primary focus of this study as I begin to explore how they struggle to recognize their individual identity and how their association with nature comes as a response to accommodate what has been rendered passive by patriarchy. I will reflect on how the ever ideal and nurturing image of nature is problematic. The place-specific behavior of the characters in my study will offer a better vision of how women combat the ever presence patriarchal horrors through interaction with nature. Such an interaction reveals how nature actually makes women conscious of their individuality. This study will convey how free spirited nature helps these women overcome their limited space laced with patriarchal beliefs of selfless nurturing where the self is denied. Building on postcolonial critics like Chandra Mohanty, I would like to explore the discursive limits set by the processes of homogenization to which Assamese women have been subjected by a range of texts. This paper will explore the changing configurations of these limits and their implications, especially with regard to their interpellation in patriarchy. Through gendered readings of representative texts like Indira Goswami's The Man from Chinnamasta and The Moth Eaten Howdah of the Tuskar and Mitra Phukan's The Collector's Wife, I will try to dismantle the essentialist binaries of nature/culture, men/women. Finally, this paper aims to dilute the 'feminine' and the 'masculine' principles and looks beyond the gynocentric essentialism of both nature and women.
\end{abstract}

Keywords: Nature, Gynocentrism, Eco Consciousness, Patriarchy, Postcolonialism

In their pursuit of finding an identity of their own, women do turn towards their association with nature and seek a source of meaning in it. These associations are mediated by patriarchal categories-both semantic and social-that in turn perpetuate certain essentialist myths that subjugate women further. As I explore the relationship between women and nature in this paper, I will try to overcome such essentialism to find out how one silenced being finds solace in another silenced entity. Deromanticising women-nature relationship would provide a better understanding of ecoconsciousness in women by challenging every form of singularity. An examination of the eco-consciousness of women paves way to see how women exercise their agency and resist any overarching patterns at their semantic colonization and homogenization. The perennially changing nature reflects the deep seated desire for change in these women. In the ever patriarchal space it is the natural surrounding that offers them a sense of place. When colonialism intertwines with patriarchy to further subjugate the already subjugated women, the

(c) AesthetixMS 2020. This Open Access article is published under a Creative Commons Attribution Non-Commercial 4.o International License (http://creativecommons.org/licenses/by-nc/4.o/), which permits non-commercial re-use, distribution, and reproduction in any medium, provided the original work is properly cited. For citation use the DOI. For commercial re-use, please contact editor@rupkatha.com. 
struggle for freedom becomes an exclusive feminist endeavour that significantly contributes to what is known as the postcolonial.

This paper will scrutinize the tradition and practices of certain communities of Assam to have a better understanding of how culture and nature interact with each other. As we gradually shift our focus from the Shakti cult, to the Vaishnavite, to the modern urbanised subjects from the texts we will encounter the changes in their principles and traditions. Despite these varied tendencies, a close reading of these texts would let us excavate how the internal gender dynamics of these communities have been historicized. My objective therefore will be to highlight the status of both women and nature in these chosen texts that present ecology as a central component.

Murray Bookchin assures that the domination of nature came after the domination of human by human (Bookchin, 1989, as cited in Plumwood, 1993, p. 15). It is important to eliminate hierarchical relationship so as to emancipate both women and nature. In order to do so gender must be freed from its normative stances. The homogenized female identity must be dismantled since a balanced ecological society calls for a sexually diverse identity which is not exclusively masculine or feminine. Certain feminist schools such as ecofeminism try to explain how both nature and women are exploited by patriarchal society. Ecofeminists examine how unjust domination of women and nature is deployed through the effect of gender norms. Ecofeminism advocates that such a norm presents an incomplete view of the world and it is important to have a worldview that values the earth as sacred and vouches for the recovery of a spiritual being (Vaughan Lee, 2013). The concept of a sacred nature, however, is motivated by the concept of nature's ability to produce and sustain life. When women and nature are connected under this category it becomes problematic as this time the idea of the nurturing nature extends also to women encouraging an essentialist discourse that perpetuates the restrictive idea of 'mother nature'. It is this idea of a nurturing nature that endorses what Vandana Shiva calls 'a feminine principle'. When Shiva enunciates the recovery of the feminine principle which she calls 'prakriti', the Hindu equivalent to nature, Shiva somewhere narrows down both nature and women. She defines Prakritias 'the feminine principle' as the basis for development which conserves. She defines feminism as ecology, and ecology as the revival of Prakriti-the source of all life (Shiva, 1988). Her use of this Hindu imagery is almost like promoting cultural politics of right-winged Hinduism. Shiva's proposition that the western model of development is the primary source of ordeal for women and environment and her suggestion about the recovery of the 'feminine principle' as its solution, is contradicted by these literary works which display that even prior to development women faced continuous subjugation. Therefore, it is unwise to make development the scapegoat for every ecological and social predicament.

This idea of closeness between women and nature also contradicts the mainstream women whose lifestyle is often anti-nature, thereby reducing the nature-woman relationship to an indigenous, eastern concept. Ecological feminism challenges these notions and claimed that it is the patriarchal trope that equates nature and women in order to degrade both. The ability of both women and nature to reproduce and nurture have led patriarchy deduce such a connection purely based on commodification of both these entities. Ecological feminism asserts that women are not seen as purely part of nature any more than men are (Plumwood, 1993); both men and nature are part of both nature and culture (Warren, 1987; King, 1989). According to Plumwood, both men and women "work for breaking down the dualistic construction of culture, but in doing so they come from different historical places and have different things to contribute to this process" (Plumwood, 1993, p.36). However, ecological feminism begins by placing women in the sphere of nature and excluding them from an oppositional culture. My analyses in this paper will therefore, look beyond any such principle that places women within a specific enclosure of either nature or culture as I attempt to show how there are no specific boundaries of nature or culture due to their continuous mingling. It is important 
not to consider women being unaffected by culture. Moreover, women and nature should not be treated as a pair since a pair of two subjugated categories is easy to be framed together. Nature and woman are two different conceptual categories that have been framed together. To speak of an intrinsic connection between the two will be to build upon the gift of patriarchy that has already maintained this conflation. An influential feminist stand will be to reclaim and celebrate difference.

This paper will try to look beyond any contention or intrinsic connection between women and nature and will focus on how nature often influences women and help women discover a part of their identity. Building on the postcolonial critic like Chandra Mohanty this study will question the production of the Third world women as a "singular monolithic subject" (Mohanty, 1988, p. 1) in order to accommodate diversity. Instead of propagating any selfless idea of women or nature where individualistic stances are once again superseded and each finds its meaning only through the other, this paper will try to portray how nature often acts as a metaphor for women living in the fringes of society.

The women characters in the chosen texts could be a reinvigorating study in this context. The characters coming from diverse backgrounds challenge every kind of homogenization. They display how rural women living in a non capitalist society are not merely satisfied with being close to nature while urban women are not insensitive to nature. These characters therefore debunk women as a singular identity and trace the dynamism of women-nature relationship. With the introduction of sensible male characters the concept of singular monolithic female is once again challenged and ecoconsciousness does not remain a gender bound idea.

In Indira Goswami's The Moth Eaten Howdah of the Tuskar, the moon is described as "a golden fish trying to escape from the net of the tangled bamboo leaves" (Goswami, 1986, p. 3). Here the moon is not only a natural trope but a metaphor for the widows, Giribala and Durga, who strive to escape social subjugation meted out to them. Interestingly, Durga's life depends on minimal necessities of life: she is a strict vegetarian and during her menstrual cycle she spends her life in a tiny hut and uses the bamboo bed. The open community bath for widows that she uses and her 'back to nature' lifestyle can be seen as how societal norms compel women to be close to nature. Although considered closer to nature compared to men, the women can never think of managing the land as it involves political consciousness. Set in the Sattra community of Assam, the novel is punctuated with the horrors of a religiously driven casteist society that fails to value individuality. Away from the capitalistic interventions of a modern life this seemingly 'ideal' village life is an instance of how societies that are living in the treasure trove of nature are not necessarily pro-women. Set in the year immediately after India's independence this novel underlines certain colonial traces: the air which was earlier full of the fragrance of the new 'ahu' paddy, which is a particular species of paddy reaped and gathered in the month of June, was replaced by the odour of the opium and nothing but opium (Goswami, 1986, p. 16 ). Like the lingering effect of the colonial endeavour patriarchy too continues to affect the life of the Sattra community. The attempt of Indranath, son of their Sattra community head called Gossain, to bring changes in the social order through conscious understanding and his left leaning tendencies evoke the need for a revolution that was required even after India attained its official independence. The novel sites how the communists tried to threaten the class based society by uniting the tenant farmers and commanding the Gossains to plough their land themselves, thereby trying to introduce a radical ideology that match the claims of radical feminists. The novel thus fails the analysis made by cultural ecological feminists like Vandana Shiva who considers traditional Indian communities to be more liberating for women. Vandana Shiva considers science and development to be the patriarchal projects. According to Shiva the common identification process of oppression for 'Third World Women' is the destructive force of science and maldevelopment (Shiva, 1988, p. 14). Her understanding of women's position is deeply governed by traditional environmental 
principles that might always be liberating for nature but not women. A sustainable environment is not emancipating if it has no space for women's dignity.

Goswami's The Man from Chinnamasta, set in colonial India around the 2,00o-year-old Kamakhya Temple of the Sakti cult, studies the constantly varying relationship between human and nature. Sakti is a concept of the Hindu religion that preaches the strength of the feminine. It refers to the divine mother who is preached for her fertility. The novel has the male priest Chinnamsta Jatadhari as the protagonist who fights against the age old ritual of animal sacrifice at the celebrated kamakhya temple of Assam. Another male character Ratnadhar is equally sensitive as he is driven to tears by the calf which is soon to be taken for sacrifice. These characters are active participants in combating the heinous animal sacrifice. The novel thus comprises such male characters whose ecological consciousness debunks the gynocentrism of conventional ecofeminist school of thought. Greeta Gard's proposal of queer ecofeminism seems relevant in this regard. She quotes "We have to examine how racism, heterosexism, classism, ageism, and sexism are all related to naturism," (Loughlin, 1993, as cited in Gaard, 1997, p. 148). The perspective of queer is an attempt to break apart the gender binaries to develop a broader understanding of nature and culture. It is what Chaia Heller calls "a process of becoming aware of and unlearning ideologies of racism, sexism, heterosexism, and ableism so that we may cease to reduce our idea of nature to a dark, heterosexual, "beautiful mother" (Heller, 1993, as cited in Gaard, 1997, p. 148).

Known to commemorate the menstrual cycle of the Kamakhya Goddess, the temple celebrates the female body for being the creator of life. The temple is considered to be the yoni peeth, which is the sacred site in Indian mythology where the genitals of goddess Durga had fallen. This site, therefore, serves as the embodiment of femininity. However, the female body is valued till it serves patriarchy. The self-abnegated ritual of women during the 'ambubachi' is a strikingly paradoxical feature surrounding the practices of that very Hindu community which claims to celebrate the female body and its muliebrity. Ambubachi, according to Hindu philosophy, is that time of the year when 'Mother Earth' is considered to menstruate. However, the widows whose fertility is assumed to have gone to waste due to lack of a male partner are forced to follow certain rituals that sometimes prove derogatory to the female body and serves as a scathing attack on the female identity. Furthermore, the discrimination of 'sterile' women, are instances of how the womb is venerated as long as it breeds. The 'Ma! Ma!' chanting of priest Jatadhari echoes the superiority of the 'mother' for its ability to sustain life. There is an intrinsic misogyny in this idea of motherhood as it overshadows all other female bodies who do not share the experience of motherhood. The obsession with the idea of the 'mother' is stifling for women as evident in the character of Dorothy Brown, who is neglected by her husband for being 'infertile'. The attempted rape and murder of Dorothy despite her being a colonial representative, says that women are forever colonized.

The thought of rural women sharing an intimate bond with nature as opposed to the urban women is debunked by Mitra Phukan's protagonist. Phukan's The Collector's Wife portrays the urban upper class Rukmini to have found solace by looking at the river from her window. She wonders about the greatness of the river and ruminates what kept her shallow all these days (Phukan, 2005, p. 65). Her urbanity has not killed her ecological consciousness. Bidhibala's passive existence in The Man from Chinnamasta while fighting the dominant males of her family makes her capable of understanding the trauma that the voiceless calf experiences right before sacrifice. Dorothy's healing alliance with the river Brahmaputra after she shifts at its bank asserts the ecological consciousness she shares with the other women. The continuous struggle with patriarchal norms is what binds together these women from diverse socio-economic and cultural backgrounds.

Dorothy's shift near the river and her suppression similar to the traditional Indian women around her makes Dorothy a hybrid character of the colonial domain. Her presence opens up a new 
shared space exclusive to women that transgresses all colonial boundaries to produce a unified need for freedom. Dorothy defines the postcolonial as a feminist space that goes beyond geographical boundaries to pin point how patriarchal power relations is the only colonizing principle.

This study shows how nature and women have been accepted as two separate living entities who do not find meaning only through the other. While various schools of thought like Green Politics, Ecocriticism and Ecofeminism strive to address a holistic view of nature that in turn would emancipate women, Women's cause becomes all the more dependent on when and how nature will be liberated. However, at the core of freedom lies the recognition for the need to be free, the consciousness for a complete individual identity. It is the development and the nurturing of such a consciousness that could finally endow this marginalized section to find the self within the patriarchal domain.

The recognition of individuality is a pivotal conclusion drawn in this study. It is the acceptance of individuality that ignites the quest for identity in these women. It is their individual stances that help them develop an eco-consciousness which does not let one entity overshadow the other but let one recognize the need for a distinctive identity. These characters echo an already existing sense of the self and how a free-spirited nature further endorses a need for freedom of these selves. Here nature may be a subconscious presence in everyday life along with being a constant conscious presence for some. The relationship between the two is thus multifaceted. However, nature is not merely a stimulant but rather an inspiration for metamorphosis.

\section{References}

Eaubonne, F. (1974). Feminism or Death. P.Horay.

Gaard, G. (2008). Toward a Queer Ecofeminism, 12.

Goswami, I. (2005). The Moth-Eaten Howdah of the Tusker. Rupa.

Goswami, I. (2006). The Man From Chinnamasta. Katha.

Heller, C. (1993). For the love of nature: Ecology and the cult of the romantic. In Greta Gaard (Ed.), Ecofeminism: Women, Animals, Nature.(pp.219-242). Temple University Press.

Tiffin, H, Huggan, G. (2007). Green Postcolonialism. Interventions, 9 (1), 1-11. https://doi.org/10.1080/13698010601173783

Merchant, C. (1992). Radical Ecology: The Search for a Liveble World . Routledge.

Miles, M., and Shiva, V. (1993). Ecofeminism. Zed books.

Mohanty, C.T. (1988). Under Western Eyes: Feminist Scholarship and Colonial Discourses. Feminist Review, 30, 61-88. https://doi.org/10.1057/fr.1988.42

Mukherjee, P. (2010). Postcolonial Environments: Nature, Culture and the Contemporary Indian Novel in English. Palgrave Macmillan.

Loughlin, E. (1993). Questioning sour grapes: Ecofeminism and the United Farm Workers grape boycott. In Greta Gaard (Eds.), Ecofeminism: Women, Animals, Nature. (46-166) Temple University Press.

Phukan, M. (2005). The Collector's Wife. Penguin Books India. 
Plumwood, V. (1991). Nature, Self, and Gender: Feminism, Environmental Philosophy, And The Critique of Rationalism. Hypatia, 6 (1), 3-27. https://doi.org/10.1111/j.1527-2001.1991.tboozo6.x

Plumwood, V. (1994). Feminism and the Mastery of Nature. Routledge.

Ruether, R. (1975). New Woman, New Earth: Sexist Ideologies and Human Liberation. Seabury Press.

Sen, S. (1999). Tribes and Castes of Assam: Anthropology and Sociology. Gyan Publishing House.

Shiva, V. (1988). Staying Alive: Women, Ecology and Survival in India. Kali for Women.

Smith, L.T. (1999). Decolonising Methodologies. Zed Books.

Tiba, T. R. (Ed.). (2010). Scheduled Tribes of Northeast India. B. R. Publishing Coorporation.

Warren, K. (1996). Ecological Feminist Philosophies: An Overview of the Issues. Indiana University Press.

Warren, K. (1996). Ecofeminism: Women, Culture, Nature. Indiana University Press. 